\title{
Evaluation of Toxoplasma gondii seropositivity and the results of IgG avidity test of patients with suspected Toxoplasmosis
}

\section{Toksoplasmosis şüpheli hastalarda Toksoplasma gondii seropozitifliğinin ve IgG avidite test sonuçlarının değerlendirilmesi}

\section{Salih Maçinn ${ }^{1}$, Duygu Fındık ${ }^{1}$, Aslıhan Demircan², Uğur Arslan ${ }^{1}$, Hatice Türrk Dağı ${ }^{1}$}

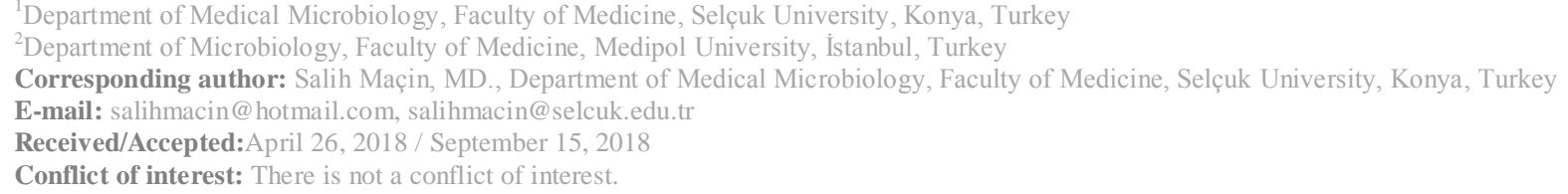

\section{SUMMARY}

Introduction: Toxoplasma gondii is an obligate intracellular protozoan belongs to the phylum Apicomplexa. T. gondii has two parts in lifecycle. While the sexual part of the lifecycle occurs in domestic and wild cats, asexual part occurs in any mammal.

Eating undercooked meat containing tissue cysts or drinking water contaminated with oocytes from feline feces cause toxoplasmosis infection. Clinically, infections can go unnoticed or could cause signs and symptoms vary depending on the immune status of the patient and the clinical setting like ocular disease or congenital toxoplasmosis.

Objective: The aim of this study was to investigate the seroprevalance of Toxoplasma gondii IgG and IgM in patients with suspected toxoplasmosis.

Method: In this study, seropositivity of antibodies against T.gondii in patients with suspected toxoplasmosis was retrospectively evaluated in Medical Microbiology Laboratory of Selcuk University Medical Faculty between January 2013 and December 2016. Anti-T. gondii immunoglobulin M (IgM), immunoglobulin G (IgG) antibodies and $\operatorname{IgG}$ avidity tests were studied in 7051 serum samples by using the VIDAS (BioMérieux, France) kits and the Enzyme Linked Fluorescence Assay technique.

Results: In all 7051 patients, seropositivity rates of anti-T. gondii $\operatorname{IgM}$ and $\operatorname{IgG}$ antibodies were 2.44 and $29.53 \%$, respectively. High avidity rate was $78.36 \%$ in 171 patients. Seropositivity rates of toxoplasma IgM antibodies in female and male patients were 2.80 and $1.14 \%$, while IgG seropositivity rates were 34.17 and $22.91 \%$, respectively.

Conclusions: The importance of searching the seropositivity of toxoplasmosis, which is still considered as an important health problem in especially reproductive women, must be emphasized. In addition, measures should be taken to raise awareness of hygiene in our region in terms of water, foods and sanitation.

Keywords: Avidity, Ig G, Ig M, Toxoplasma gondii, seroprevalance 
bir memelide ortaya çıkabilir. İnsanlarda $T$. gondii'ye bağlı enfeksiyonlar, ookist içeren kedi dışkısı ile kontamine yiyeceklerin pişmemiş veya az pişmiş yenmesi ile meydana gelmektedir.

T. gondii enfeksiyonları genellikle asemptomatiktir. Hastanın bağışıklık durumuna ve oküler hastalık veya konjenital toksoplazmozis gibi klinik durumuna bağlı olarak değişik belirti ve semptomlara da neden olabilir.

Amaç: Bu çalışmanın amacı, toksoplasmosis şüpheli hastalarda Toxoplasma gondii IgM ve IgG seroprevalansının araştırılmasıdır.

Yöntem: Bu çalışmada, toksoplazmozisden şüphelenilen hastalarda Ocak 2013 ile Aralık 2016 tarihleri arasında Selçuk Üniversitesi Tıp Fakültesi Tıbbi Mikrobiyoloji Laboratuvarı'nda toksoplazma antikorlarının seropozitifliği retrospektif olarak değerlendirildi. Anti-T.gondii immünoglobülin M (IgM), immünoglobülin G (IgG) antikorları ve $\operatorname{IgG}$ avidite testleri 7051 serum örneğinde VIDAS (BioMérieux, Fransa) kitleri ve Enzim Bağl1 Floresans Testi tekniği kullanılarak çalışıldı.

Bulgular: 7051 hastada seropozitiflik oranları anti-T. gondii IgM ve IgG antikorları için sırasıly \% 2.44 ve \% 29.53 'tü. Yüksek avidite oranı 171 hastanın \% 78.36'sında saptandı. Kadın ve erkek hastalarda toksoplazma IgM antikorlarının seropozitiflik oranları sırasıyla \%2.80 ve 1.14 iken IgG seropozitiflik oranları ise sırasıyla $\% 34.17$ ve $\% 22.91$ idi.

Sonuç: Özellikle üreme çağındaki kadınlarda önemli bir sağlık problemi olarak görülen toksoplazmozisin seropozitifliğinin araştırılmasının önemi vurgulanmalıdır. Ayrıca bölgemizde su, gıda ve temizlik açısından hijyen farkındalığının arttırılması ile ilgili önlemler alınmalıdır.

Anahtar sözcükler: Avidite, Ig G, Ig M, Toxoplasma gondii, seroprevalans

\section{INTRODUCTION}

Toxoplasma gondii is an obligate intracellular protozoan parasite that belongs to the phylum Apicomplexa, subclass coccidia. T. gondii has two parts in lifecycle. While the sexual part of the lifecycle occurs in domestic and wild cats, asexual part occurs in any mammal. Human beings can be infected with $T$. gondii by ingestion or handling of undercooked or raw meat containing tissue cysts, drinking water contaminated with oocysts from feline feces, transplantation of infected organs or ingestion of oocysts through close contact with infected cat or feline feces ${ }^{1}$.

Most individuals are infected inadvertently, thus the specific route of transmission cannot usually be established. Variations in seroprevalence of $T$. gondii seem to correlate with eating and hygiene habits of a population. This finding lends support to the contention that the oral route is the major source of infection ${ }^{2}$.

It's known that approximately $1 / 3$ of the world population is infected by $T$. gondii. Clinically, infection can go unnoticed or could cause signs and symptoms that vary depending on the immune status of the patient and the clinical setting like ocular disease or congenital toxoplasmosis ${ }^{3-4}$. As an effective vaccine has not yet been developed, continuous and detailed epidemiological surveillance is required to estimate the risk of infection, especially in pregnant women, and the likelihood of reactivation in immunocompromised individuals ${ }^{5}$.

\section{MATERIAL AND METHODS}

In this study, seropositivity of antibodies against toxoplasma in patients with suspected toxoplasmosis was retrospectively evaluated in Medical Microbiology Laboratory of Selcuk University Medical Faculty between January 2013 and December 2016. Blood samples of patients were centrifuged at $4.500 \mathrm{rpm}$ for 15 minutes. Then serum fraction of blood samples was extracted. Anti-T. gondii immunoglobulin $\mathrm{M}$ (IgM), immunoglobulin $\mathrm{G}$ (IgG) antibodies and IgG avidity were studied in 7051 serum samples by using the VIDAS (BioMérieux, France) kits and the Enzyme Linked Fluorescence Assay technique. For $\mathrm{IgG},>8 \mathrm{UI} / \mathrm{ml}$ test value and for $\operatorname{IgM},>0.65$ index test value were accepted positive. $>0.3$ avidity index was interpreted as high.

\section{RESULTS}

In all 7051 patients, seropositivity rates of anti-T. gondii $\operatorname{IgM}$ and $\mathrm{IgG}$ antibodies were 2.44 and $29.53 \%$, respectively. At Table 1, there are all rates of anti- $T$. gondii $\mathrm{IgM}$ and $\mathrm{IgG}$ antibodies. Seropositivity rates of toxoplasma IgM antibodies in female and male patients were 2.80 and $1.14 \%$, respectively. IgG seropositivity rates in female and male patients were 34.17 and $22.91 \%$, respectively. 
Seropositivity rate of anti-T. gondii IgM antibodies in women at fertility ages was shown at Table 2 . The rate of anti- $T$. gondii IgM positivity was $2.92 \%$ in 3249 women of fertile age.
As seen at Table 3 , high avidity rate was $78.36 \%$ in 134 of 171 patients. 40 patients had anti-T. gondii IgM antibodies.

Table 1. Prevalence of IgG and IgM Toxoplasma gondii-specific antibodies by gender

\begin{tabular}{|c|c|c|c|c|c|}
\hline Gender & $\begin{array}{c}\text { IgM-positive } \\
\text { No }(\boldsymbol{\%})\end{array}$ & $\begin{array}{c}\text { IgM-negative } \\
\text { No (\%) }\end{array}$ & $\begin{array}{c}\text { IgG-positive } \\
\text { No (\%) }\end{array}$ & $\begin{array}{c}\text { IgG-negative } \\
\text { No (\%) }\end{array}$ & $\begin{array}{c}\text { Total } \\
\text { No (\%) }\end{array}$ \\
\hline Female & $108(2.80)$ & $3754(97.20)$ & $392(34.17)$ & $755(65.83)$ & $5152(73.06)$ \\
\hline Male & $12(1.14)$ & $1039(98.86)$ & $184(22.91)$ & $619(77.09)$ & $1899(26.94)$ \\
\hline Total & $120(2.44)$ & $4793(97.56)$ & $576(29.53)$ & $1374(70.47)$ & $7051(100)$ \\
\hline
\end{tabular}

Table 2. IgM rates of women of childbearing age (15-49 ages)

\begin{tabular}{|l|c|c|}
\hline \multirow{2}{*}{} & \multicolumn{2}{|c|}{ Ig M } \\
\cline { 2 - 3 } & No & \% \\
\hline Positive & 95 & 2.92 \\
\hline Negative & 3149 & 96.92 \\
\hline Equivocal & 5 & 0.15 \\
\hline Total & 3249 & 100 \\
\hline
\end{tabular}

Table 3. Distribution of IgG and IgM compared to IgG avidity patterns in all patients

\begin{tabular}{|l|c|c|}
\hline \multicolumn{1}{|c|}{ IgG Avidity } & \multicolumn{1}{|c|}{$\begin{array}{c}\text { IgG-positive } \\
\text { IgM-positive } \\
\text { No (\%) }\end{array}$} & $\begin{array}{c}\text { IgG-positive } \\
\text { IgM-negative } \\
\text { No (\%) }\end{array}$ \\
\hline $\begin{array}{l}\text { Hihg Avidity (>0.3) } \\
\text { 134/171 (78.36\%) }\end{array}$ & $40(29.85)$ & $94(70.15)$ \\
\hline $\begin{array}{l}\text { Low Avidity (0.2<) } \\
\text { 27/171 (15.39\%) }\end{array}$ & $13(48.14)$ & $14(51.86)$ \\
\hline $\begin{array}{l}\text { Borderline (0.2-0.3) } \\
\text { 10/171 (6.15\%) }\end{array}$ & $7(70)$ & $3(30)$ \\
\hline $\begin{array}{l}\text { Total } \\
\text { 171/171 (100\%) }\end{array}$ & $60(35.08)$ & $111(64.92)$ \\
\hline
\end{tabular}

\section{DISCUSSION}

The seropositivity of toxoplasmosis varies in many countries and even in different regions within a country, depending on the differences in socioeconomic situation, development levels, climate, and geography, which has been reported to range between $12-90 \%$. The IgG seropositivity was reported to be $37 \%, 29 \%$, and $24 \%$ in 1984 , 1997, and 2004, respectively in Greece, which is in the same climate zone as Turkey ${ }^{6}$. Researchers have related this decreasing trend to socioeconomic development.

$\operatorname{IgG}$ and $\operatorname{IgM}$ seropositivity has been reported as $23.3-37.1 \%$ and $0.1-1.9 \%$ in patients prediagnosed with toxoplasmosis in Turkey ${ }^{7,8,9}$. This difference may be attributed to the size of the working groups, socio-demographic characteristics, and habits, as well as the climatic characteristics and test sensitivity. In this study, seropositivity of $\mathrm{IgG}$ was higher than of $\mathrm{IgM}$. IgG and IgM seropositivity were found to be 29.53 
and $2.44 \%$, respectively. In our region, these seropositivity rates show similarity with seropositivity rates of the other studies in Turkey. This contribute that $T$. gondii $\operatorname{IgG}$ antibodies are reflection of past or previous infection, while IgM reflects recent or acute $T$. gondii infection.

Many studies have investigated the relationship between $T$. gondii seropositivity and gender both in Turkey and in the world. In a study conducted in Brazil, IgG seropositivity was found to be $63.4 \%$ in women and $79 \%$ in men ${ }^{10}$. In a study from United States, the seropositivity was found to be $23.3 \%$ and $21.8 \%$ in women and men, respectively ${ }^{11}$. In our study, seropositivity rates of toxoplasma $\operatorname{IgM}$ and $\operatorname{IgG}$ antibodies were 2.80 and $34.17 \%$ in women and 1.14 and $22.91 \%$ in men, respectively. This may be attributed to the fact that as opposed to men, women contact contaminated raw food and are at a higher risk of exposure to oocysts disseminated by cats during household chores and gardening work.

The IgG avidity tests that have been in practical use in recent years allow reliable differentiation between acute primary infection, reactivation, and/ or re-infection in a single serum sample. This differentiation has clinical significance, especially in pregnant women and immunocompromised patients. IgG antibodies against the antigen on first exposure during the primary infection show low avidity in the first weeks and then acquire gradually higher avidity with increased maturity.

Alver at al. ${ }^{12}$ found the high avidity in 136 (81.9\%), borderline in $17(10.2 \%)$, and low in 13 (7.9\%) patients in their study. In our study we found the high avidity in $134(78.36 \%)$, borderline in $10(6.15 \%)$, and low in $27(15.39 \%)$ of 171 samples. In our study, 60 patients $(35.08 \%)$ had IgM positivity, of whom $13(21.66 \%)$ had low avidity, suggesting a recent previous infection, while $40(66.66 \%)$ had high avidity, suggesting a past or previous infection. Avidity of seven patients who had IgM positivity was borderline (11.66\%). Also 111 patients (64.92\%) had IgM negativity. 94 (70.15\%) of them had high avidity.

In pregnant women, multiparity, older age, and a history of poor obstetric outcome have been previously described as risk factors for $T$. gondii infections ${ }^{13-14}$. In a study conducted in Turkey, seroprevalence of $T$. gondii $\operatorname{IgM}$ were determined among women of childbearing age (15-49 ages). Positive rate of the $T$. gondii IgM antibodies was found as $4.6 \%$. In our study, Ig M rate was found lower as $2.92 \%{ }^{15}$. Enter at al. ${ }^{16}$ found Toxoplasma gondii Ig $\mathrm{M}$ rate as $1.5 \%$ seropositivity among pregnant women.

\section{CONCLUSION}

Toxoplasma gondii is able to infect all warmblooded animals and chronically infects approximately one-third of the world's human population . T. gondii can cause serious clinical consequences and even death in immunocompromised individuals or patients undergoing immunosuppressive treatments or during pregnancy ${ }^{17}$. Regular surveillance studies on toxoplasmosis seroprevalence must continue in our country in order to prediction of congenital toxoplasmosis risk, determination of screening strategies and important for informing the seronegative pregnancies on the prevention methods.

\section{REFERENCES}

1. Tenter AM, Heckeroth AR, Weiss LM. Toxoplasma gondii: from animals to humans. Int J Parasitol, 2000; 30: 121758.

2. Muqbil NA, Alqubatii MA. Seropositivity of toxoplasmosis among women in Aden city, Yemen. Archives of Biomedical Sciences, 2014; 2: 42-50.

3. Cook AJ, Gilbert RE, Buffolano W, et al. Sources of toxoplasma infection in pregnant women: European multicentre case-control study. BMJ 2000; 321: 14247.

4. Tian A L, Gu YL, Zhou N, Cong W, Li G $\mathrm{X}$, et al. Seroprevalence of Toxoplasma gondii infection in arthritis patients in eastern China. Infec Dis Poverty 2017; 6, 153.

5. Remington JS, McLeod R, Thulliez P, Desmonts G. Toxoplasmosis. In: Remington JS, Klein J, eds. Infectious diseases of the fetus and newborn infant, 5th edn. Philadelphia: WB Saunders, 2001; 205-346.

6. Diza E, Frantzidou F, Souliou E, Arvanitidou M, Gioula G, Antoniadis A. Seroprevalence of Toxoplasma gondii in northern Greece during the last 20 years. Clin Microbiol Infect 2005; 11: 719-23.

7. Bölük S, Özyurt BC, Girginkardeşler N, Kilimcioğlu AA. Evaluation of Serological Results of Patients with Suspected Toxoplasmosis Admitted to the Medical Parasitology Laboratory of Celal Bayar University Hospital between 2006- 
2010. Turkiye Parazitol Derg 201236, $137-41$.

8. Așc1 Z, Akgün S. Afyon İlinde Bir Seroloji Laboratuvarna Toxoplasma gondii (T. gondii) Antikorları Araştırılması Amaciyla Başvuran Olgulara Ait Sonuçların Değerlendirilmesi. Turkiye Parazitol Derg 2015; 39, 9-12.

9. Aycan Ö M, Miman Ö, Atambay M, Karaman Ü, Çelik T et al. A Last SevenYear Investigation of the Seropositivity of Toxoplasma Gondii in Our Hospital. J Turgut Ozal Med Cent 2008; 15,3:199201.

10. Coelha RA, Kobayashi M, Carvalho LB Jr. Prevalance of IgG antibodies specific to Toxoplasma gondii among blood donors in Recife, Northeast Brazil. Rev Inst Med Trop Sao Paulo 2003; 45: 22931. 17.

11. Jones JL, Kruszon-Moran D, Wilson M, Mc Quillan G, Navin T, McAuley JB. Toxoplasma gondii infection in the United States: seroprevalance and risk factor. Am J of Epidemiol 2001; 154: 357-65.

12. Alver O, Göral G, Ercan, İ. Investigation of Serological Results of Patients with Suspected Toxoplasmosis Admitted to the ELISA Laboratory of Uludag University Hospital between 2002-2008. Türkiye Parazitol Derg 2014; 38 (3), 141.

13. Andiappan H, Nissapatorn V, Sawangjaroen N, Htut Nyunt M, Lau YL, et al.. Comparative study on Toxoplasma infection between Malaysian and Myanmar pregnant women. Parasit Vectors 2014; 7: 564.

14. Sakikawa $M$, Noda $S$, Hanaoka $M$, Nakayama H, Hojo S, Kakinoki S, Nakata M, Yasuda T, Ikenoue T, Kojima T, 2012. Anti- Toxoplasma antibody prevalence, primary infection rate, and risk factors in a study of toxoplasmosis in 4,466 pregnant women in Japan. Clin Vaccine Immunol 19: 365-367.

15. Tekin A, Deveci Ö, Yula E. The seroprevalence of antibodies against Toxoplasma gondii and Rubella virus among childbearing age women in
Mardin province. J Clin Exp Invest 2010; 1(2): 81-5.

16. van Enter BJ, Lau YL, Ling CL, Watthanaworawit W, Sukthana Y, et al. Seroprevalence of Toxoplasma gondii Infection in Refugee and Migrant Pregnant Women along the ThailandMyanmar Border. Am J Trop Med hyg 2017;97(1), 232-5.

17. McLeod R, Kieffer F, Sautter M, Hosten $\mathrm{T}$, Pelloux H. Why prevent, diagnose and treat congenital toxoplasmosis? Mem Inst Oswaldo Cruz. 2009;104:320-44. 